\title{
IMPLEMENTASI SISTEM PENDUKUNG KEPUTUSAN UNTUK MEMPREDIKSI HASIL PRODUKSI TANAMAN JAGUNG MENGGUNAKAN TEOREMA BAYES
}

\author{
Sisilia Daeng Bakka Mau', Frengky Tedy ${ }^{2}$, Patrisius Batarius ${ }^{3}$, Emerensiana Ngaga ${ }^{4}$ \\ ${ }^{1234}$ Program Studi Ilmu Komputer, Fakultas Teknik, Universitas Katolik Widya Mandira \\ Jl.Jend. Achmad Yani No.50-52, Kupang, Nusa Tenggara Timur \\ Email: ${ }^{1}$ Sisilia901@gmail.com, ${ }^{2}$ Fredyondang@gmail.com, ${ }^{3}$ Patrisiusbatarius@gmail.com, \\ ${ }^{4}$ Lora.ngaga@gmail.com
}

\begin{abstract}
ABSTRAK
Tanaman jagung (Zea mays L.) di Indonesia terutama di Provinsi Nusa Tenggara Timur merupakan salah satu komoditi utama dari hasil pertanian dan menjadi makanan pokok utama yang dikonsumsi setiap hari oleh masyarakat Timor. Biji jagung sebagai salah satu sumber karbohidrat dan protein dapat diolah menjadi berbagai jenis makanan. Bertambahnya jumlah konsumsi masyarakat NTT terhadap pangan jagung menyebabkan terjadinya peningkatan permintaan akan tanaman pangan jagung. Dengan demikian maka perlu dilakukan peningkatan produktivitas tanaman jagung sehingga dapat memenuhi permintaan masyarakat akan tanaman jagung seperti penggunaan varietas unggul, pemupukan dan pengaturan jarak tanam. Selain cara tersebut, juga dapat dilakukan melalui sistem tanam secara tumpangsari, karena dapat memelihara kelembaban dan kadar air tanah serta mengurangi erosi dan meningkatkan kesuburan tanah. Tujuan penelitian ini adalah menerapkan berbagai faktor yang digunakan dalam proses sistem tanam tumpangsari yaitu curah hujan, suhu, kelembapan, jarak tanam, dan tata letak tanam untuk meningkatkan produtivitas tanaman jagung. Metode yang digunakan untuk mengukur tingkat akurasi prediksi hasil produksi tanaman jagung menggunakan teorema bayes. Hasil penelitian ini berupa sebuah aplikasi sistem pendukung keputusan yang dapat membantu dan mempermudah petani untuk meningkatkan hasil produksi tanaman jagung.
\end{abstract}

Kata Kunci : sistem pendukung keputusan, prediksi hasil produksi jagung, teorema bayes

\begin{abstract}
Maize (Zea mays L.) in Indonesia, especially in the province of East Nusa Tenggara is one of the main commodities of agricultural products and is the main staple food that is consumed daily by the Timorese people. Corn kernels as a source of carbohydrates and protein can be processed into various types of food. Increasing the amount of consumption of NTT people towards corn food causes an increase in demand for corn food plants. Thus, it is necessary to increase the productivity of corn plants so that they can meet the demand of the community for corn plants such as the use of high yielding varieties, fertilizing and planting spacing. In addition to these methods, it can also be done through intercropping, because it can maintain soil moisture and moisture content and reduce erosion and increase soil fertility. The purpose of this study is to apply various factors used in the intercropping system, namely rainfall, temperature, humidity, spacing, and layout for planting to increase the productivity of maize. The method used to measure the accuracy of prediction of the yield of corn crops using the Bayes theorem. The results of this study are in the form of a decision support system application that can help and facilitate farmers to increase the yield of maize production.
\end{abstract}

Keywords: decision support system, predictions of corn production results, bayes theorem

\section{PENDAHULUAN}

\subsection{Latar Belakang}

Tanaman jagung (Zea mays L.) di Indonesia terutama di Provinsi Nusa Tenggara Timur merupakan salah satu komoditi utama untuk bahan pangan dan pakan. Biji jagung sebagai salah satu sumber karbohidrat dan protein dapat diolah menjadi berbagai jenis makanan dan merupakan bahan baku industri pakan. Bertambahnya jumlah konsumsi penduduk terhadap jagung dan kebutuhan industri pakan ternak menyebabkan terjadinya peningkatan permintaan akan tanaman pangan jagung. Hal ini tidak akan terpenuhi bila produksi jagung tidak ditingkatkan. Berdasarkan data Badan Pusat Statistik Kabupaten Timor Tengah Selatan (TTS), khususnya di Kecamatan Mollo Utara pada tahun 2016 produksi jagung mencapai 13.176 ton/ha, tetapi pada tahun 2017 produksi jagung mengalami penurunan dimana produksi jagung yang dihasilkan sebesar 7.056 ton/ha. Dari data tersebut dapat dilihat bahwa produksi jagung di Kabupaten TTS khususunya di Kecamatan Mollo Utara mengalamai penurunan produksi.

Salah satu cara untuk menanggulangi penurunan produksi jagung, pemerintah melakukan berbagai upaya untuk meningkatkan produktivitas produksi jagung seperti penggunaan varietas unggul, pemupukan dan pengaturan jarak tanam. Selain cara tersebut, untuk meningkatkan produktivitas lahan dapat dilakukan melalui sistem tanam secara tumpangsari (intercropping system), karena dapat memelihara kelembaban dan kadar air tanah serta 
mengurangi erosi dan meningkatkan kesuburan tanah. Tumpangsari adalah sistem bertanam dimana lebih dari satu macam tanaman ditanam secara simultan di lahan yang sama diatur dalam baris atau kumpulan baris secara berselang-seling.

Berdasarkan data fakta pada lahan pertanian di Kecamatan Mollo Utara, menunjukan bahwa penggunaan metode tumpangsari tidak seperti metode yang ada, petani menanam tanpa melihat jarak tanam yang sesuai dengan metode tumpangsari. Penentuan penggunaan metode tumpangsari didasarkan pada faktor-faktor penentu seperti : (1) curah hujan, (2) suhu, (3) kelembaban, (4) jarak tanaman, (5) tata letak tanaman. Ketidakpastian penerapan faktor-faktor tersebut dapat menyebabkan hasil produksi dan produktivitas tanaman jagung menggunakan metode tumpangsari menjadi tidak sesuai seperti yang diharapkan dan kemungkinan terjadi gagal panen yang dapat mengakibatkan kemerosotan kehidupan ekonomi petani. Dengan banyaknya berbagai faktor yang mempengaruhi sistem tanam tumpangsari membuat petani cukup kebingungan dalam menerapkan sistem tanam tumpangsari untuk tanaman jagung.

Pengambilan keputusan yang tepat merupakan salah satu langkah manajerial yang strategi bagi para petani, karena dalam proses pengambilan keputusan yang baik tidak mudah dilakukan mengingat banyak faktor yang harus dipertimbangkan. Oleh karena itu, dibutuhkan sebuah sistem pengambil keputusan yang membantu pihak pengambil keputusan untuk dapat mengorganisir faktor-faktor yang harus dipertimbangkan secara obyektif.

Penentuan penggunaan metode tumpangsari yang tepat pada tanaman jagung merupakan permasalahan yang dihadapi para petani karena terdapat berbagai kriteria yang harus dipertimbangkan sebelum diputuskan penanggulangannya. Berdasarkan permasalahan yang terjadi maka dibangunlah sebuah sistem yang dapat membantu petani dalam pengambilan keputusan untuk menentukan hasil produksi tanaman jagung menggunakan metode teorema bayes dengan memperhatikan 2 variabel penentu yaitu kerapatan tanaman dan penggunaan jarak tanam sebagai variabel utama dalam menentukan hasil produksi tanaman jagung dengan sistem tanam tumpangsari.

\subsection{Rumusan Masalah}

Berdasarkan permasalahan yang telah diuraikan pada latar belakang maka dapar dirumusakan permasalahannya adalah bagaimana implementasi sistem pendukung keputusan untuk memprediksi hasil produkasi tanaman jagung menggunakan metode teorema bayes.

\subsection{Batasan Masalah}

Adapun batasan masalah dari penelitian ini adalah sebagai berikut : a. Faktor-faktor yang digunakan dalam penentuan hasil produksi tanaman jagung dengan sistem kelembapan, jarak tanam, dan tata letak tanam

b. Metode yang digunakan untuk mengukur tingkat akurasi prediksi hasil produksi tanaman jagung menggunakan teorema bayes.

\subsection{Tujuan dan Manfaat Penelitian}

Tujuan dari penelitian ini adalah menerapkan faktor - faktor yang digunakan dalam proses sistem tanam tumpangsari yaitu curah hujan, suhu, kelembapan, jarak tanam, dan tata letak tanam untuk meningkatkan produtivitas tanaman jagung menggunakan sebuah sistem pendukung keputusan. Sedangkan manfaat penelitian ini adalah membantu dan mempermudah petani untuk meningkatkan hasil produksi tanaman jagung.

\subsection{Referensi}

Penelitian yang dilakukan Adikara et,al pada tahun 2018 tentang sistem pendukung keputusan pemilihan varietas unggul jagung hibrida menggunakan metode AHP-SMART menghasilkan sebuah sistem berupa peringkat varietas jagung mulai dari terbaik hingga terburuk[4].

Penelitian yang dilakukan Rahayu et,al pada tahun 2018 tentang sistem pendukung keputusan pemilihan tanaman pangan berdasarkan kondisi tanah menggunakan metode electre dan topsis menghasilkan sebuah sistem dimana pada lahan tertentu akan didapat tanaman apa yang paling cocok untuk ditanam pada lahan tersebut.

Penelitian yang dilakukan Supriono pada tahun 2017 tentang implementasi metode bayes dalam penentuan varietas jagung berbasis web, menghasilkan sebuah sistem yang dapat membantu petani dalam menentukan varietas jagung yang cepat dan akurat yang dapat diakses darimana saja selama ada jaringan internet.

Berdasarkan dari penelitian-penelitian yang telah dilakukan, maka fokus dalam penelitian ini adalah merancang bangun aplikasi sistem pendukung keputusan untuk memprediksi hasil produksi tanaman jagung dengan sistem tanam tumpangsari yang meliputi beberapa faktor yaitu suhu, curah hujan, kelembaban, jarak tanam dan tata letak tanam, sedangkan metode teorema bayes digunakan untuk menghitung tingkat akurasi prediksi hasil produksi tanaman jagung.

Teori probabilitas adalah cara untuk mengungkapkan pengetahuan atau kepercayaan bahwa suatu kejadian akan berlaku atau telah terjadi.

Teorema Bayes yang digunakan pada proses pengambilan keputusan tidak terlepas dari teori peluang sebagai konsep dasar. Teorema Bayes dikenal sebagai rumus dasar untuk peluang bersyarat yang tidak bebas. Teorema Bayes diadopsi dari nama penemunya yaitu Thomas Bayes sekitar tahun 1950. Teorema Bayes adalah sebuah teori kondisi probabilitas yang memperhitungkan probabilitas 
sebuah kejadian (hipotesis) bergantung pada kejadian lain (bukti). Metode Teorema Bayes merupakan teknik yang digunakan untuk melakukan analisis dalam pengambilan keputusan terbaik dari sejumlah alternatif. Perhitungan nilai setiap kriteria untuk mendapatkan hasil keputusan penentuan produksi tanaman jagung ditentukan berdasarkan perhitungan Teorema Bayes sebagai berikut :

$$
P\left(H_{i} \mid E_{1} E_{2} \ldots E_{n}\right)=\frac{P\left(E_{1} E_{2} \ldots E_{n} \mid H_{i}\right) \cdot P\left(H_{i}\right)}{\sum_{k=1}^{m} P\left(E_{1} E_{2} \ldots E_{n} \mid H_{k}\right) \cdot P\left(H_{k}\right)}
$$

Keterangan :

$$
\begin{aligned}
& \mathrm{P}\left(\mathrm{H}_{\mathrm{i}} \mid \mathrm{E}\right)=\begin{array}{l}
\text { probabilitas hipotesis } \mathrm{H} \text { terjadi jika evidance } \mathrm{E} \\
\text { terjadi }
\end{array} \\
& \mathrm{P}\left(\mathrm{E} \mid \mathrm{H}_{\mathrm{i}}\right)=\begin{array}{l}
\text { probabilitas munculnya evidance } \mathrm{E}, \text { jika } \\
\text { hipotesis } \mathrm{H} \text { terjadi }
\end{array} \\
& \mathrm{P}\left(\mathrm{H}_{\mathrm{i}}\right)=\begin{array}{l}
\text { probabilitas hipotesis } \mathrm{H} \text { tanpa memandang } \\
\text { evidance apapun }
\end{array} \\
& \mathrm{P}(\mathrm{E})=\begin{array}{l}
\text { probabilitas evidance } \mathrm{E} \text { tanpa memandang } \\
\text { apapun }
\end{array}
\end{aligned}
$$

\section{PEMBAHASAN}

Penelitian ini dilakukan dengan tujuan untuk merancang bangun sebuah aplikasi sistem pendukung keputusan menggunakan metode teorema bayes yang dapat membantu petani untuk memprediksi hasil produksi jagung sebagai hasil utama dan kacang-kacangan yaitu kacang tali dan kacang hijau sebagai tanaman pendamping dalam sistem tanam tumpangsari.

Langkah-langkah dalam pengembangan sistem pendukung keputusan untuk menentukan hasil produksi jagung dengan sistem tanam tumpangsari menggunakan metode teorema bayes adalah sebagai berikut : (1) Tahap analisis dilakukan untuk mengetahui kebutuhan user terhadap variabelvariabel yang menjadi faktor penentu dalam memprediksi hasil produksi tanaman jagung. (2) Tahap perancangan sistem terdiri dari desain bagan alur sistem (systems Flowchart), desain database (ERD), desain proses (DFD), desain user interface meliputi desain input form, output form dan report, desain software. (3) Tahap implementasi ini dilakukan pembuatan kode program berdasarkan hasil perancangan yang telah dibuat. (4) Tahap pengujian sistem dilakukan terhadap fungsionalitas yang ada dalam sistem menggunakan pengujian Black Box Test.

\subsection{Tahap Analisis}

Kriteria yang digunakan dalam penentuan hasil produksi jagung dengan sistem tanam tumpangsarian adalah sebagai berikut :

a. Curah hujan adalah jumlah atau keadaan hujan pada suatu wilayah tertentu.

b. Kelembaban adalah banyaknya kadar uap air yang ada di udara.

c. Suhu udara merupakan derajat panas atau dingin yang dapat diukur berdasarkan skala tertentu. d. Tata letak tanaman adalah cara menanam pada lubang tanam.

e. Jarak tanam adalah jarak antara 1 lubang tanam dengan yang lain.

Kelima kriteria di atas kemudian akan dihitung menggunakan metode teorema bayes untuk

\begin{tabular}{|c|c|c|}
\hline Kriteria & Range & Belief \\
\hline$C 1:$ & $85-450$ & 0,40 \\
\hline \multirow{3}{*}{$\begin{array}{l}\text { Curah Hujan } \\
(\mathrm{mm} / \mathrm{bln})\end{array}$} & $451-793$ & 0,30 \\
\hline & $794-1147$ & 0,20 \\
\hline & $1148-1500$ & 0,10 \\
\hline & $20-25$ & 0,40 \\
\hline C2 : & $26-29$ & 0,30 \\
\hline \multirow{3}{*}{$\operatorname{Suhu}\left({ }^{\circ} \mathrm{C}\right)$} & $30-33$ & 0,20 \\
\hline & $34-37$ & 0,10 \\
\hline & $65-70$ & 0,40 \\
\hline C3: & $71-76$ & 0,30 \\
\hline \multirow[t]{2}{*}{ Kelembapan (\%) } & $77-82$ & 0,20 \\
\hline & $83-89$ & 0,10 \\
\hline \multirow{4}{*}{$\begin{array}{c}C 4: \\
\text { Jarak Tanam } \\
(\mathrm{cm})\end{array}$} & $25 \times 70$ & 0,40 \\
\hline & $25 \times 80$ & 0,30 \\
\hline & $25 \times 100$ & 0,20 \\
\hline & Bebas & 0,10 \\
\hline \multirow{5}{*}{$\begin{array}{c}\text { C5 : } \\
\text { Tata Letak } \\
\text { Tanam }\end{array}$} & Selang Seling & 0,60 \\
\hline & $\begin{array}{l}\text { (Kacang dan } \\
\text { Jagung) }\end{array}$ & \\
\hline & & 030 \\
\hline & $\begin{array}{c}\text { Kacang dalam } 1 \\
\text { Lubang }\end{array}$ & 0,30 \\
\hline & Campuran & 0,10 \\
\hline
\end{tabular}
menentukan hasil produksi jagung terbaik, sehingga dapat memprediksi hasil produksi jagung sebelum produksi jagung itu dilakukan.

Kriteria yang digunakan untuk penentuan prediksi hasil produksi jagung dengan sistem tanam tumpangsari seperti ditunjukkan pada tabel 1 di bawah ini :

Tabel 1. Kriteria Penilaian

\subsection{Tahap Perancangan Sistem}

Proses sistem pendukung keputusan prediksi hasil produksi jagung dengan sistem tanam tumpangsari menggunakan metode teorema bayes menggunakan sebuah flowchart sistem. Dalam flowchart sistem terdapat penjelasan proses kerja sistem secara keseluruhan berdasarkan data-data alternatif dan kriteria yang digunakan untuk menghasilkan informasi yang lengkap. Data kemudian diinput ke dalam suatu database kemudian diproses untuk menghasilkan output berupa nilai alternatif terbaik dalam memprediksi hasil produksi jagung. Berikut gambar flowchart sistem yang dibuat untuk memprediksi hasil produksi jagung dengan sistem tanam tumpangsari menggunakan metode teorema bayes pada gambar 1 di bawah ini : 


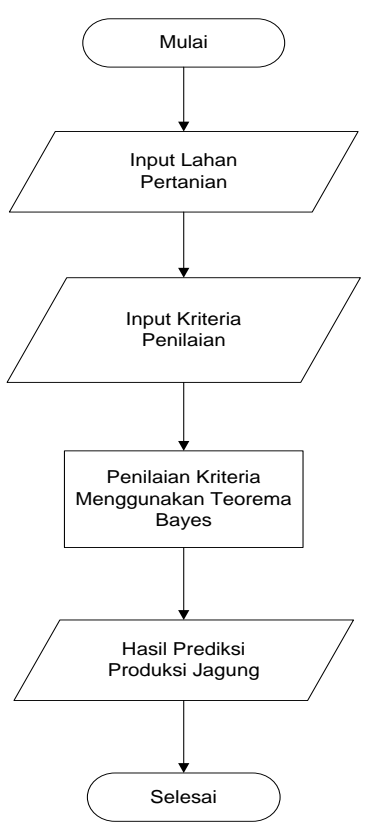

\section{Gambar 1. Flowchart Sistem}

\subsection{Tahap Implementasi}

Pada tahap implementasi, rancangan form yang telah dibuat kemudian diaplikasikan dengan menggunakan bahasa pemrograman $P H P$ dengan database MySql. Program hasil implementasi dari perancangan yang ditelah dibuat antara lain sebagai berikut :

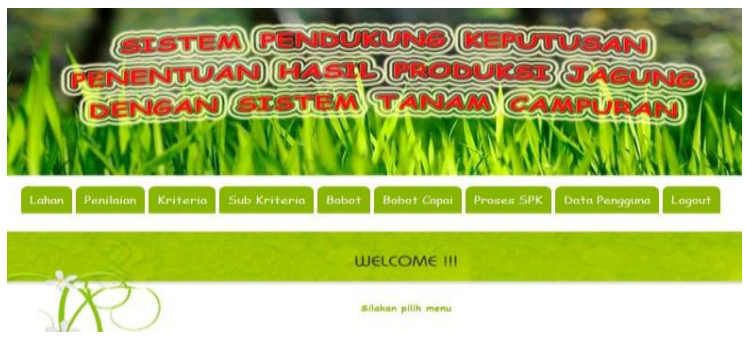

\section{Gambar 2. Menu Utama}

Gambar 2 menampilkan menu utama pada saat aplikasi dijalankan. Form ini terdiri dari field lahan, penilaian, kriteria, sub kriteria, bobot, bobot capai, proses spk, data pengguna dan log out.

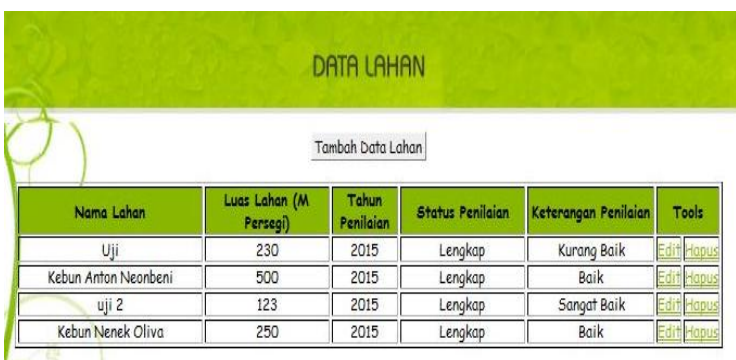

Gambar 3. Data Lahan

Gambar 3 menampilkan data lahan yang terdiri atas beberapa field yaitu : nama lahan, luas lahan, tahun penilaian, status penilaian, keterangan penilaian. Form ini digunakan untuk mengisi data lahan beserta kriteria yang akan digunakan untuk proses penilaian menggunakan metode teorema bayes.

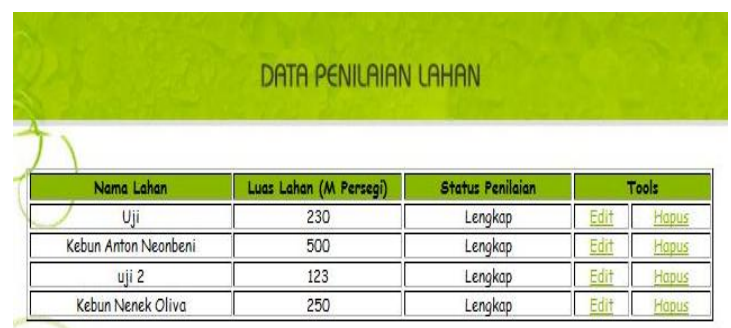

\section{Gambar 4. Form Penilaian Lahan}

Gambar 4 menampilkan data penilaian lahan yang terdiri dari field nama lahan, luas lahan dan status penilaian. Form ini digunakan untuk mengolah data hasil penilaian prediksi produksi jagung dengan sistem tanam tumpangsari menggunakan metode teorema bayes.

\subsection{Tahap Pengujian Perhitungan}

Pada tahap ini akan dilakukan proses perhitungan beberapa lahan untuk setiap kriteria yang digunakan menggunakan metode teorema bayes seperti terlihat pada tabel 2 di bawah ini :

Tabel 2. Nilai Kriteria Penilaian

\begin{tabular}{ccllll}
\hline Lahan & $\mathbf{C}_{\mathbf{1}}$ & $\mathbf{C}_{\mathbf{2}}$ & $\mathbf{C}_{\mathbf{3}}$ & $\mathbf{C}_{\mathbf{4}}$ & $\mathbf{C}_{\mathbf{5}}$ \\
\hline 1 & 0,40 & 0,30 & 0,30 & 0,40 & 0,60 \\
2 & 0,30 & 0,30 & 0,30 & 0,30 & 0,30 \\
3 & 0,20 & 0,30 & 0,30 & 0,20 & 0,60 \\
4 & 0,30 & 0,30 & 0,30 & 0,20 & 0,60 \\
5 & 0,20 & 0,30 & 0,40 & 0,20 & 0,10 \\
6 & 0,20 & 0,10 & 0,10 & 0,30 & 0,30 \\
7 & 0,40 & 0,40 & 0,30 & 0,30 & 0,30 \\
8 & 0,30 & 0,30 & 0,40 & 0,40 & 0,60 \\
9 & 0,30 & 0,30 & 0,40 & 0,20 & 0,60 \\
10 & 0,40 & 0,40 & 0,30 & 0,40 & 0,60 \\
\hline
\end{tabular}

Pada tabel 2 terdapat 10 (sepuluh) data uji coba lahan pertanian yang sesuai dengan kriteria yang digunakan dalam proses penentuan hasil produksi tanaman jagung dengan sistem tanam tumpangsari menggunakan metode bayes yaitu curah hujan, suhu, kelembapan, jarak tanam dan tata letak tanaman. Nilai-nilai tersebut sudah dikonversikan sesuai dengan nilai bobot kriteria yang terdapat pada tabel 1.

Setelah nilai kriteria telah diubah sesuai dengan bobot kriteria maka selanjutnya akan dilakukan perhitungan menggunakan metode teorema bayes untuk setiap lahan sesuai dengan kriteria yang telah ditentukan. Hasil perhitungan dilakukan secara simulasi dan aplikasi yang dapat dilihat pada tabel 3 sebagai berikut : 
Tabel 3. Hasil Pengujian

\begin{tabular}{cccc}
\hline Lahan & Simulasi & Aplikasi & Error \% \\
\hline 1 & 0,328 & 0,329 & 0,001 \\
2 & 0,054 & 0,055 & 0,001 \\
3 & 0,064 & 0,064 & 0,000 \\
4 & 0,105 & 0,105 & 0,000 \\
5 & 0,023 & 0,020 & 0,003 \\
6 & 0,005 & 0,005 & 0,000 \\
7 & 0,235 & 0,236 & 0,001 \\
8 & 0,357 & 0,358 & 0,001 \\
9 & 0,297 & 0,3 & 0,003 \\
10 & 0,337 & 0,34 & 0,003 \\
\hline
\end{tabular}

Berdasarkan tabel 3 untuk hasil pengujian menunjukkan bahwa perhitungan yang dilakukan dengan simulasi dan aplikasi sistem pendukung keputusan untuk memprediksi hasil produksi tanaman jagung dengan sistem tanam tumpangsari menggunakan metode teorema bayes memperoleh hasil rata-rata kesalahan sebesar $0,013 \%$.

\section{KESIMPULAN}

Dari hasil penelitian yang dilakukan dengan sistem pendukung keputusan untuk memprediksi hasil produksi tanaman jagung dengan sistem tanam tumpangsari menggunakan metode teorema bayes dapat disimpulkan sebagai berikut :

1. Sistem yang dibangun akan sangat membantu dan mempermudah petani dalam proses pengambilan keputusan untuk memprediksi hasil produksi tanaman jagung.

2. Metode teorema bayes yang digunakan dalam perhitungan dapat memberikan hasil perhitungan terbaik karena menggunakan nilai probabilitas yaitu evidance ganda dan hipotesis ganda.Semakin banyak evidance dan hipotesis maka semakin baik nilai yang akan didapat dalam proses perhitungan menggunakan metode teorema bayes.

3. Hasil perbandingan perhitungan menggunakan simulasi dan apalikasi diperoleh nilai rata-rata error yang kecil yaitu $0,013 \%$.

Saran untuk pengembangan aplikasi system pendukung keputusan untuk memprediksi hasil produksi tanaman jagung dengan sistem tanam tumpangsari adalah :

1. Penambahan faktor-faktor penentu dalam meningkatkan produksi tanaman jagung selain dari 5 faktor yang telah digunakan dalam aplikasi ini.

2. Menggunakan metode lainnya dalam menghitung tingkat akurasi prediksi hasil produksi tanaman jagung.

3. Pengembangan aplikasi lebih lanjut bisa dibangun berbasis mobile.

\section{PUSTAKA}

Abi, D. 2013. Pengaruh Frekuensi Pupuk Organik Cair Pada Tumpangsari Jagung (zea mays,L) Dengan Beberapa Varietas Kacang Hijau (vigna radiata, $L$ ), Skripsi tidak diterbitkan. Universitas Timor Kefamenanu.

Adikara, R. M .A. ,et al. 2018. Sistem Pendukung Keputusan Pemilihan Varietas Unggul Jagung Hibrida Menggunakan Metode AHP-SMART. Jurnal Pengembangan Teknologi Informasi dan Ilmu Komputer, Vol.2.No.8.

Badan Pusat Statistik Kabupaten Timor Tengah Selatan, 2019, (http://timortengahselatankab.bps.go.id diakses 14 Mei 2019)

Kusumadewi, S. 2003. Atificial Intelligence (Teknik dan Aplikasinya), Yogyakarta: Graha.

Rahayu,N.P., et al. 2018. Sistem Pendukung Keputusan Pemilihan Tanaman Pangan Berdasarkan Kondisi Tanah Menggunakan Metode Electre dan Topsis. Jurnal Pengembangan Teknologi Informasi dan Ilmu Komputer, Vol.2.No.10.

Supriana, I. W. 2016. Perancangan Sistem Pendukung Keputusan Dalam Penentuan Penggunaan Pupuk Kimia Pada Tanaman Jagung Menggunakan Metode AHP. Jurnal Teknologi Informasi dan Komputer, Vol.2, No.1.

Supriono, B. 2017. Implementasi Metode Bayes Dalam Penentuan Varietas Jagung Berbasis Web. Jurnal Simki_Techsain, Vol.01,No.06.

Yahdin, S., et al. 2008. Aplikasi Pengambilan Keputusan Pada Perencanaan Produk Berdasarkan Teorema Bayes, Media Informatika, Vol.6, No.1. 